\title{
Banking Passivity and Regulatory Failure in Emerging Markets: Theory and Evidence from the Czech Republic
}

\author{
By: Jan Hanousek and Gerard Roland
}

William Davidson Working Paper Number 424

July 2001 


\title{
Banking Passivity and Regulatory Failure in Emerging Markets: Theory and Evidence from the Czech republic.
}

\author{
Jan Hanousek, CERGE-EI ${ }^{+}$ \\ and \\ Gerard Roland, UC Berkeley, ECARES, CEPR and CERGE-EI*
}

First version, July 2001

\footnotetext{
+ Jan Hanousek is Associate Professor of Economics at CERGE-EI,, a joint workplace of Charles University and The Academy of Sciences of the Czech Republic, Prague, where he holds the Citibank Chair in Financial Markets.jan.hanousek@cerge-ei.cz Thanks to Randall K. Filer for his suggestions and comments.

*Gérard Roland acknowledges support from ACE grant No P 98-1008-R.
} 


\title{
Banking Passivity and Regulatory Failure in Emerging Markets: Theory and Evidence from the Czech republic.
}

\begin{abstract}
$\underline{\text { Abstract }}$
We present a model of bank passivity and regulatory failure. Banks with low equity positions have more incentives to be passive in liquidating bad loans. We show that they tend to hide distress from regulatory authorities and are ready to offer a higher rate of interest in order to attract deposits compared to banks that are not in distress. Therefore, higher deposit rates may act as an early warning signal of bank failure. We provide empirical evidence that the balance sheet information collected by the Czech National Bank is not a better predictor of bank failure than higher deposit rates. This confirms the importance of asymmetric information between banks and the regulator and suggests the usefulness of looking at deposit rate differentials as early signals of distress in emerging market economies where banks' equity positions are often low.
\end{abstract}

Keywords: Bank failures, bank supervision, Czech banking crisis, default risk, transitional economies

JEL classification: C53, E58, G21, G33 


\section{INTRODUCTION}

Banking crises in emerging market economies have been a regular feature in recent years. Mexico, the East Asian economies, Russia and Turkey were all hit hard within less than 10 years and almost all countries in Central and Eastern Europe have experienced turbulence in their banking and financial sectors ${ }^{1}$.

Such crises usually reveal bank passivity, i.e. a failure to liquidate bad loans. Instead, banks engage in covering up bad loans, which most often leads to a worsening of their financial situation. These issues have been widely studied. (For transition economies, e.g., Mitchell et al., 1993, 1997; Berglöf and Roland, 1997.) Banking regulation is usually seen as the remedy to bank passivity and cover-ups. In the aftermath of the East Asian crisis, there was strong insistence on the introduction of rules creating greater transparency in the banking sector. However, achieving better regulation is not just a matter of changing the rules and increasing reporting requirements of banks to regulators. Better rules will not by themselves prevent banks from hiding important information from the regulator. Indeed, there is a fundamental problem of asymmetric information between the regulator and banks and high costs of monitoring usually do not allow informational asymmetries to be easily overcome. (Aghion, Bolton and Fries, 1998 analyse the issue of how to elicit truthful information from the banks.)

In this paper, our analysis is more positive than normative in that we try to understand the behaviour of banks and regulators in the transition context, and more generally in the context of emerging market economies. We highlight the role of 
interest rates in relation to bank passivity and regulatory failure. Banks that are in greater danger of financial distress and have relatively low equity positions are shown to have more incentives to behave passively toward bad loans than banks with higher equity positions. Those banks also have a greater tendency to hide a situation of distress from regulatory authorities, thus making it more difficult for the latter to detect distress early on. We also demonstrate that banks with low equity positions will be ready to offer a higher rate of interest than banks that are not in distress in order to attract deposits. Higher deposit rates may thus act as an early warning signal of bank failure, a feature that has already been noticed in the empirical finance literature (see e.g.. Ellis and Flannery, 1992; Wheelock and Wilson, 1995).

We confront the results of the model with balance sheet information of banks collected by the Czech National Bank. We focus on data from the Czech banking crisis 1994 to1996. We show that these data are not a better predictor of banking failure than higher deposit rates, therefore showing that the regulator does (did) not have privileged information on banks, despite the existing reporting rules.

The idea that competition between banks on depositor rates is harmful has been present for a long time in the banking literature. Kane (1989) and Cole et al. (1995) have analysed the effect of deregulation, and in particular the elimination of deposit rate ceilings (regulation Q), on the $\mathrm{S}$ and $\mathrm{L}$ crisis in the US. More recent empirical work has established a correlation between increases in interest rates and the occurrences of financial crises (Demirgüc-Kunt and Detragiache, 1997). While the incentive effects of equity regulations on various forms of risk-taking are pretty well

\footnotetext{
${ }^{1}$ In the early 1990s, for example, Poland's banks experienced a crisis, followed in 1994-1996 by the failure of several small banks in the Czech Republic, and severe problems in Latvia in 1995 when four of its large banks failed. For a detailed description and overall picture see EBRD, 1996-1997.
} 
understood (see e.g. Rochet, 1992; Bolton and Freixas, 2000, and the subject of a very vast literature, there have been surprisingly few models focusing on the perverse effects of deposit rate competition. An important exception is Hellman, et al., 2000). They constructed a model showing that high equity requirements without deposit rate ceilings lead to inefficiently high amounts of equity requirements in order to push the bank to avoid excessive risk-taking. As stated above, our model is less normative than positive, modelling the effects of differences in equity on interest rate competition and on subsequent bank failure with the purpose of testing empirically this relationship. Moreover, we focus on banks' passivity in hardening the budget constraints of firms rather than on their choice of assets. In other words, we focus more on the issue of the quality of a bank's loan portfolio, an important issue in understanding financial crises, rather than on its risk-taking behaviour.

The paper is organised as follows: section 2 introduces the theoretical model; section 3 describes the emergence of the Czech banking sector; section 4 presents the empirical evidence in the case of Czech Republic's banking crisis; and the final section carries conclusions and possible policy implications. 


\section{THE MODEL}

The model combines elements from the Mitchell (1997) and the DewatripontMaskin (1995) model and is close to the Berglöf and Roland (1997) model. The latter is augmented to analyze the interest rate setting by low and high-equity banks. We first show that banks in distress will be ready to offer a higher rate of interest to attract deposits compared to banks that are not in distress, and thus, why higher deposit rates may act as an early warning signal of bank failure. Second, we show why the bank regulator may not have more information than the market.

Consider two different types of banks that differ only in terms of their equity. Low-equity banks only have equity $E$ in amount of 1 . High-equity banks have equity in amount of $E=W$, assumed to be "large". Consider the following game between banks, enterprises and a banking regulator.

At $t=0$, enterprises submit projects to banks. We assume each bank faces the same pool of projects. Even though banks differ in their equity endowment, we assume that they all have only one liquid unit of funds, which is exactly the amount required to finance all the projects facing a bank. There is, however, asymmetric information on project types. A proportion $\alpha$ of "good" projects yield at $t=1$ a verifiable return $R_{g}$ to the bank and a nonverifiable private benefit $B_{g}$ to the enterprise management ${ }^{2}$. A proportion $(1-\alpha)$ of projects are "poor" projects that yield the same results only if the enterprise exerts effort. If no effort is exerted, then the project yields no verifiable return or private benefit at $t=1$.

\footnotetext{
${ }^{2}$ The private benefit $B_{g}$ is then net of effort.
} 
The project can then either be liquidated or refinanced. If it is liquidated, then it yields at $t=2$ a liquidation value $L$ for the bank and a private benefit of 0 for the enterprise. If it is refinanced, however, one unit of fund is necessary per project refinanced. In this case, there is a probability $q$ that the project yields at $t=2$ a verifiable return of $R_{p}$ and a probability $(1-q)$ that it yields a liquidation value $L_{s}<L$. We also assume that $L_{s}<1$. In both cases (good or bad verifiable return), a private benefit of $B_{p}$ is assumed to accrue to the enterprise management. Refinancing of poor projects is assumed to happen via funds generated at $t=0$ but also by attracting retail deposits. It is assumed that $\alpha R_{g}<(1-\alpha)$ so that refinancing always requires attracting new deposits in an amount of (1- $\alpha)-\alpha R_{g}$. We assume that the total supply of funds is inelastic and lower than $(1-\alpha)-\alpha R_{g}$ so that banks compete for deposits by bidding up the deposit interest rate $r$.

The bank's decisions to liquidate or refinance matter to the regulator. We assume that at $t=2$, at the end of the game, the regulator must bail out banks that have a negative net position, due to deposit insurance. The regulator thus has an interest in preventing ex ante such bailouts by engaging in monitoring the banks. The regulator is particularly interested in preventing banks from "gambling for resurrection" by refinancing poor projects, knowing that the downside will be bearded by the regulator. To be precise, we assume that $q\left(R_{p^{-}}-1\right)+(1-q)\left(L_{s}-1\right)<1$, i.e. that the net expected return on a bad project is negative and thus is expected to deteriorate the balance sheets of banks. Whether or not banks will want to engage in gambling for resurrection is still, however, a very different matter that we will analyze more in detail below. We will assume for now that there are grounds for such a temptation by assuming that $q\left(R_{p^{-}}\right.$ $1)+(1-q)\left(L_{s}-1\right)>L$, i.e. that the net ex post return from refinancing is strictly positive. 
Indeed, since the initial funds injected are a sunk cost, the bank will only compare the ex post return to refinancing and to liquidation. The expected ex post return from refinancing is thus assumed to be higher than the expected return to liquidation.

We will say that a bank is active when it liquidates poor projects at $t=1$ and that it is passive when it refinances these projects. The enterprise's behavior depends very much on whether the bank is active or not. We assume that $B_{p}>B_{g}>0$. The inequality on the left means that if banks are passive, enterprises with poor projects prefer to choose low effort because they derive a higher net private benefit. On the other hand, the inequality on the right means that enterprises prefer to choose high effort because they are better off compared to the alternative of liquidation. Thus, if banks are active and are expected to liquidate poor projects, i.e. if enterprises have hard budget constraints, enterprises will choose a high effort level. Conversely, if they have soft budget constraints and expect to be refinanced, they will choose not to exert effort.

We assume that the bank monitoring activity of the regulator takes the form of deciding on a probability $D$ of detecting whether the firm is passive or not. When a bank is detected being passive, the bank management is fired and has a payoff of 0 . We assume that the bank management derives a private benefit $\rho$ from keeping their jobs and thus get hurt when fired. Bank managers thus potentially trade off the expected benefits from gambling for resurrection with the expected costs of getting fired. 
Now that we have defined the relations between enterprises and banks and between banks and regulators, let us define exactly the timing of decisions in the full game.

At $t=0$, the regulator decides on a level of $D$ and spends $C(D)$ on monitoring activities. We assume that $C(D)$ is a convex function. The bank lends money to enterprises and enterprises with poor projects decide on their effort level.

At $t=1$, returns of projects are observed. Banks decide to be active or passive, and compete to attract deposits for refinancing of poor projects if that is their choice. Call $a \in[0,1]$ a bank's choice of level of "activity" in liquidating poor projects. Directly afterwards, the government monitors and fires passive bank managers it has detected.

At $t=2$, the government bails out banks with a negative net position.

Even though we have a three-tier hierarchy, the analysis can concentrate on the government-bank relationship. Indeed, enterprise behavior is easy to characterize. It is obvious that firms have soft budget constraints if and only if $(1-a) B_{p} \geq B_{g}$. Given that $B_{p}>B_{g}$ firms will have hard budget constraints only if the bank is sufficiently active, i.e. if $a>\widetilde{a}=1-\frac{B_{g}}{B_{p}}$.

The next question we ask is critical. What is the maximum interest rate banks are willing to offer, as a function of their equity, at which they prefer to refinance poor projects rather than to liquidate them?

If a bank is active and thus if enterprises exert high effort, bank management will have at $t=2$ a payoff of 


$$
E-1+R_{g}+\rho
$$

It is clear in this case that the bank will be in a healthy position whatever its initial equity position since $R_{g}+\rho>0$. However, in order to understand the incentive of a bank to be passive or active, we must look at the bank's incentive after low effort has been exerted. If the bank decides to be active, its expected position will be

$$
E-1+\alpha R_{g}+(1-\alpha) L
$$

If however it decides to be passive, its expected position will be

$$
\begin{aligned}
& q\left[\left(E-1+(1-\alpha) R_{p}-\left[(1-\alpha)-\alpha R_{g}\right](1+r)\right]+\right. \\
& (1-q) \max \left\{0, E-1+(1-\alpha) L_{s}-\left[(1-\alpha)-\alpha R_{g}\right](1+r)\right\}
\end{aligned} .
$$

In particular, depending on the level of equity, the downside payoff after refinancing will differ. Indeed, if $E=1$, then the downside payoff is equal to $(1-\alpha) L_{s}-\left[(1-\alpha)-\alpha R_{g}\right](1+r)$, which is always $<0$ since we have assumed that $L_{s}<1$. Thus, when the bank has a large initial equity position, its expected position is

$$
\left.E-1+(1-\alpha)\left[q R_{p}+(1-q) L_{s}\right]-\left[(1-\alpha)-\alpha R_{g}\right](1+r)\right]
$$

However, when it has a low initial equity position, its expected position is

$$
q\left[(1-\alpha) R_{p}-\left[(1-\alpha)-\alpha R_{g}\right](1+r)\right]
$$

where the expression between brackets is assumed to be positive. Note that a bank with a lower equity position will, everything else equal, benefit from the safety net of deposit insurance in the bad-return outcome. We can then compare the net return from refinancing for a high-equity bank and for a low-equity bank. In particular, if $r^{H}$ is the 
interest rate offered by the high-equity bank and $r^{L}$ is the interest rate offered by the low-equity bank, the return on refinancing

$$
\begin{aligned}
& (1-\alpha)\left[q R_{p}+(1-q) L_{s}\right]-\alpha R_{g}-\left[(1-\alpha)-\alpha R_{g}\right]\left(1+r^{H}\right)= \\
& q\left[(1-\alpha) R_{p}-\alpha R_{g}-\left[(1-\alpha)-\alpha R_{g}\right]\left(1+r^{L}\right)\right] .
\end{aligned}
$$

Developing this expression, we get

$$
\left[(1-\alpha)-\alpha R_{g}\right]\left(q r^{L}-r^{H}\right)=(1-q)(1-\alpha)\left[1-L_{s}\right]
$$

Since $L_{s}<1$, it is clear that the right-hand-side of the equation is positive (and thus the left-hand side). Therefore, since $\alpha R_{g}<(1-\alpha)$, we have that $r^{L}>q r^{L}>r^{H}$.

This result leads us to the following propositions:

Proposition 1: Low-equity banks will offer a higher deposit interest rate than high-equity banks. Moreover, high-equity banks will be active while low-equity banks will be passive.

The first part of proposition 1 follows directly from the fact that the same return can be obtained with a higher interest rate for a low equity bank since the lowequity bank will expect to benefit from deposit insurance whereas the high-equity bank will not. The second part of the proposition follows from the fact that interest rate competition between low and high-equity banks will take place until the highequity banks drop out of the competition. Indeed, since the latter have a lower return from refinancing for a given interest rate, the upbidding of interest rates will lead high

\footnotetext{
${ }^{3}$ Note that the return to refinancing is not the same as the expected position of the bank. The former must include expenditure $\alpha R_{g}$ whereas when we compute the latter $\alpha R_{g}$ is netted out because it is both an income and an expenditure.
} 
equity banks earlier to a situation where they prefer to be active, in which case they get a return of $(1-\alpha) L$. This result shows us why higher deposit interest rates can act as a warning signal for bank distress. Indeed, in competing with high-equity banks, low-equity banks will be ready to offer a higher interest rate precisely because they expect to be in a distress.

We now analyze the decision of the regulator to monitor banks and see how this in turn can affect banks' incentives. We will look at the incentives of banks with a low equity level.

They will choose to be active if and only if

$$
\begin{aligned}
& \alpha R_{g}+(1-\alpha) L+\rho>(1-\mathrm{D})\left\{\mathrm{q}\left[\left((1-\alpha) R_{p}-\left[(1-\alpha)-\alpha R_{g}\right]\left(1+r^{L}\right)\right]+\rho\right\},\right. \\
& \text { i.e., if } D>\widetilde{D}=\frac{(1-\alpha)\left[q\left(R_{p}-\left(1+r^{L}\right)-L\right]-(1-q) \alpha R_{g}+q \alpha R_{g} r^{L}\right.}{\mathrm{q}\left[(1-\alpha) \mathrm{R}_{\mathrm{p}}-\left[(1-\alpha)-\alpha \mathrm{R}_{\mathrm{g}}\right]\left(1+\mathrm{r}^{\mathrm{L}}\right)\right]+\rho}
\end{aligned}
$$

Below this threshold, banks will choose to be active and above it they will choose to be passive. The regulator therefore need never go beyond $\widetilde{D}$ to achieve the required incentive effect. The only question becomes whether the regulator gains from paying the cost of $C(\widetilde{D})$ to obtain active behavior from banks, with the result of hardening the budget constraints of enterprises, or whether that cost is higher than the cost of ex post bail out of banks. Thus, we thus get the following proposition.

Proposition 2: Effective bank regulation will only take place if

$$
C(\widetilde{D}) \leq(1-q)\left[\left((1-\alpha)-\alpha R_{g}\right)\left(1+r^{L}\right)-(1-\alpha) L_{s}\right]
$$

If this inequality is violated, then it does not pay to monitor banks effectively. This comparison hinges on the relative costs of monitoring banks versus the costs of 
bank bailout. In transition economies, both are likely to be high. Whichever is more important then becomes a question that must be determined empirically.

Note that the regulator need not necessarily engage in active monitoring of the bank in order to detect passivity. Indeed, the regulator may use information on profit taxes paid by banks to infer whether banks were passive or not. Indeed, in equilibrium, active banks generate at $t=1$ profits $R_{g}$ and pay taxes $t R_{g}$, assuming a proportional tax on profits. Passive banks, on the other hand, generate at $t=1$ profits $\alpha R_{g}$ and pay taxes $\alpha t R_{g}$. Thus, by observing tax filings, the regulator could easily detect passive banks. In that case, a bank that intends to be passive would need to "hide" and report more profits than it actually made. In other words, a passive bank would have to report (and pay taxes on) the profits of an active bank, i.e. pay $t R_{g}$ instead of $\alpha t R_{g}$. This is a case in which hiding passivity has a cost for the bank.

Again, in order to analyze the bank's incentive, we must compare its expected positions when being active and passive in the event that firms have exerted low effort. In the former (out of equilibrium) case, the bank will choose to be active, will not try to hide, and will pay taxes only on its real profits. In the latter case, the bank will pay excess taxes but will benefit from its gamble for resurrection. A bank will thus choose to be active if

$$
\alpha R_{g}(1-t)+(1-\alpha) L+\rho>q\left[(1-\alpha) R_{p}-t R_{g}-\left((1-\alpha)-\alpha R_{g}\right)\left(1+r^{L}\right)\right]+\rho
$$

This expression can be rewritten as

\footnotetext{
${ }^{4}$ The model is of course very stylized, but in reality, banks with a worsening portfolio would report lower profits to the tax authorities and this could be a useful source of information for bank regulators.
} 


$$
(q-\alpha) t R_{g}>(1-\alpha)\left[q\left(R_{p}-\left(1+r^{L}\right)\right)-L\right]-\alpha\left(1-q\left(1+r^{L}\right)\right) R_{g} .
$$

The left-hand side represents the net cost of being passive and hiding whereas the right hand side represents the net benefit. What does inspection of this inequality tell us?

First, note that if $q<\alpha$, there is no real cost to hide! Indeed, even though taxes are paid in amount $t R_{g}$ instead of $\alpha t R_{g}$, since the downside outcome of refinancing is insured, it is as if taxes were only paid on $q t R_{g}$, i.e. on the upside outcome. If, however, $q>\alpha$, then a higher tax rate on profit discourages banks from hiding since it increases the cost of doing so. This discussion is expressed in the following proposition.

Proposition 3: If detection of passivity can occur via tax filings, then:

a) if $q<\alpha$, banks have no cost of hiding being passive;

b) if $q>\alpha, \quad$ there is a threshold tax rate $\tilde{t}=\frac{(1-\alpha)\left[q\left(R_{p}-\left(1+r^{L}\right)\right)-L\right]-\alpha\left(1-q\left(1+r^{L}\right)\right) R_{g}}{q-\alpha}$ above which banks are discouraged from hiding. 


\section{BACKGROUND ON THE CZECH BANKING SECTOR}

The first step in reforming the banking sector was law No. 130/1989, approved on November 15, 1989 creating a central bank, the State Bank of Czechoslovakia (hereafter SBCS). According to this law, the SBCS was accountable and responsible for state monetary policy, but not for commercial banking. The law regulating the commercial banks and the savings and loans sector was approved month later on December 13, 1989. This law enabled two-tier banking, in that it brought into being commercial banks and set the basic rules for their operation. The Ministry of Finance was charged with regulating the banking sector. ${ }^{5}$ According to this law, interest rates were governed by the SBCS and deposits in state financial institutions were guaranteed by the state. In January 1990, the SBCS transferred its commercial banking to three newly established banks: Komerční banka (KB), Vseobecka uverova (VUB), and Investicni banka (IP, which in 1993 merged with Post office banks as IPB). On December 20, 1991 new laws on central and other banks were adopted (Nos. 21 and 22/1992). These laws, effective from February 1, 1993, established the independence of the national bank from the government and gave the SBCS the authority for banking supervision. On January 1, 1993, the Czech National Bank (CNB) took over the functions of the SBCS as a result of the split of Czechoslovakia. The laws on banks also contained clearly specified rules for granting licenses, and defined a general regulatory framework.

Unfortunately, the conditions for obtaining banking licenses were quite soft, requiring a minimum subscribed equity capital of only CZK 50 million (US\$2 million). This low requirement was increased in April 1991 to CZK 300 million 
(US\$10 million). On the other hand, the "Law on Foreign Exchange" protected the local market against foreign competition preventing firms from directly acquiring capital abroad.

With such low capital requirements the number of new banks literally exploded from early 1990, when there was a central bank plus seven banks licensed for universal banking to 23 by the end of 1990 . This trend continued with 36 banks by the end of 1991 and by 51 by the end of 1992. These newly established banks were small, with the only significant exception being Agrobanka. ${ }^{6}$ In 1993, the rate of new bank creation slowed, with only 8 new banking licenses granted (See Table 1). Between mid-1994 and 1996, the CNB decided not to grant any new bank licenses, most likely in a response to failures of small and medium-sized banks.

Due to very soft licensing procedures and insufficient screening of license candidates, many newly formed banks lacked a sufficient capital base, as well as employees equipped with proper managerial skills and business ethics. Because of their lack of capital, small and medium-sized banks began to finance clients carrying out the riskiest projects, which other banks had refused to finance. Due to the standard adverse selection problem, a higher interest rate only served to attract high-risk clients. In addition, several new banks were using deposits to extend credit to other activities of the bank's owners, or simply "tunnelling" the deposited money out of the bank. Regardless of whether the main reason was incompetence or theft, the overall effect on the cash flow and balance sheets of these banks was seriously damaging.

\footnotetext{
${ }^{5}$ The Federal Ministry of Finance supervised banks and the Ministries of Finance of Czech and Slovak Republic controlled saving and loans.

${ }^{6}$ Agrobanka, founded in 1990, became the fifth largest bank in the Czech Republic within a year.

${ }^{7}$ The Economist, September 1996: "Each of these bank failures stemmed from a deadly cocktail of mismanagement, orgiastic lending (often to bank's own stockholders), and more often than not, fraud".
} 
Several bank failures beginning in December 1993 up set public trust in the banking sector and had a strong influence on the stability of small and medium-sized banks.

As a reaction to the first three bank failures, the law on banks was amended to include obligatory insurance on deposits. This insurance covered only the deposits of citizens up to $100,000 \mathrm{CZK}$ per head and per bank with the premium being limited to 80 percent of the deposit balance on the day of a bank's closure. The amendment also increased the extent and authority of banking supervision granted to the CNB. The CNB could now impose sanctions for non-compliance ranging from enforcing corrections and imposing fines to the revocation of banking licenses.

After the introduction of deposit insurance, another bank, Ceska banka, filed for bankruptcy and the new law was applied to its clients. However, when a series of additional failures soon followed in the election year of 1996, the CNB became far more generous, with individual clients of the failed banks recovering their full deposits up to $4,000,000 \mathrm{CZK}$ in contradiction to the law precessions.

The CNB decided to cope with the resulting sensitive political problem of lost deposits by tightening the licensing procedures and introducing obligatory deposit insurance. In its efforts to stem the tide of bank failures, the CNB tried two policies. In early July 1995, it tightened its policies, increasing the minimum reserve requirements (MRR) and also unifying its rates.

\footnotetext{
${ }^{8}$ The CNB was given the authority force to fulfil several obligatory rules; approve/change bank management; give a penalty up to 50 mil. CZK; enforce reduction of shareholder's capital and its transfer to reserves if these were not sufficient; and withdraw or freeze banking licenses.
} 


\section{DATA AND RESULTS}

We were able to get access to the official data collected by the supervisory body of the CNB. ${ }^{9}$ The data set consists of 1995 monthly reports of 20 local banks 14 of which posed significant problems at some point during the study. Data on retail interest rates were published monthly in leading newspapers (or in the magazine Ekonom). The data set containing interest rates is much broader. It contains monthly rates (checking accounts, and one and two-year deposits) of all Czech local banks during the period 1994 to 1996 . For 1995 it does not make any sense to add foreign banks or their branches to our sample because of their inherent differences in terms of services, structure, financing, etc. 10

As suggested by Proposition 1, passive banks (and hence those potentially in trouble) will offer higher interest rates on their deposits. The situation in the Czech Republic is clearly depicted in Figure 1. We use symbols "1" and "0" to mark those banks that failed and survived, respectively, during the period 1994-1996. As a benchmark (denoted by "2") we use a bank that provided practically no corporate lending, and therefore for which interest rates should not reflect problems with its loan portfolio. Figure 1 exhibits a clear pattern for one-year deposits, indicating generally higher rates for problem banks, in line with the theoretical model. Moreover, the interest rates differentials between sound and problematic banks

\footnotetext{
${ }^{9}$ Let us note for completeness that there exist two sets of publicly available accounting data represented by a subset of the ASPEKT (or CEKIA) databases of the Czech capital market that covers annual reports of publicly traded banks. Unfortunately, these data sets are basically useless for applying our model for two reasons. First, the publicly available information covers only a short version of the balance sheet and it differs drastically from those data available to regulators. Second, if any additional public information exists (for example, a standard balance sheet provided by ASPEKT or CEKIA), then several variables are missing, namely for those banks that were ex-post seen as "problematic". ${ }^{10}$ Although we construct the financial ratios that have been used in models of bank failures, we must stress that our indicators do not have the same meaning as in the other studies, since all reporting to the CNB was done according to local accounting standards.
} 
become even more noticeable over time. It is thus clear that banks with higher interest rates on term deposits were more likely to fail later on.

Although Figure 1 indicates a strong pattern, we want to test whether the differences between groups are significant. Table 5 summarizes several $\mathrm{t}$-tests across different time periods and duration of term deposits. These results clearly verify that mean interest rates for problematic banks were significantly higher compared with those of sound banks. In addition, we see that since the first half of 1994, differences were statistically significant for both one and two-year term deposits. ${ }^{m}$ Moreover, the mean difference was higher for longer duration term deposits, a finding consistent with the idea of capturing default risk for the bank via retail deposit rates.

Another key component of the model is the asymmetric information between banks and the regulator regarding the extent of bad loans on banks' balance sheets. The timing of recapitalisation offers and subsequent revisions of estimates of bad loans 12 suggest that regulators have incomplete information at the time recapitalisation is offered. Since we have the official data made available to the regulator, it is particularly interesting to test empirically how well these data predict the crisis, thus giving us a rather precise idea of the quality of the information available.

Our purpose is to demonstrate that the "best" model based on the regulatory data does not provide for a very good fit 13 . Our search for the best fit is not motivated by

\footnotetext{
${ }^{11}$ We suggest excluding checking accounts from our analysis. Usually, the interest rate on these accounts is not a relevant measure of why clients opted for a particular bank. (We omit whole range of services offered by the bank.).

12 The cases of Japan and Mexico are well documented.

${ }^{13}$ There exists a literature on predicting bank failures in mature market economies (see Looney et. al., (1989); Lane et. al,. (1985), Barber et al., (1996), Hwang at al (1997); among others) based on financial indicators. However, our purpose is less to see how well those models perform in the case of the Czech
} 
data-mining considerations but rather by the need to assess the best predictions one could make on the basis of the regulatory data 14 Moreover, on the basis of our theoretical model, we should expect that adding the retail interest rate variable into an econometric model of bank failure should help predict the problem banks. One would like to test for the relative importance of regulatory data versus interest rates in helping predict bank failure. Indeed, interest rates may or may not serve as a signal for future distress. Independently of the interest rate, balance sheet data given to the regulators may or may not reflect accurately the situation of the bank depending on whether the accounting data are truthful or not. Balance sheet data may be uninformative but market data may be more informative. As seen in the model, problem banks can attract cash via a much higher interest rate on term deposits than other (i.e., "safe") banks offer. Unfortunately, this only speeds up the process of worsening bank conditions. 15

Our core empirical results are the results of the "best" logit models of the bank failures with and without interest rate variables as presented in Table $6 \stackrel{16}{6}$ The findings are rather striking. First, the financial indicators, although they were drawn from official data collected by the supervisory body of the CNB (used in Model I), did not prove a significantly better predictor of actual bank failure than one-year deposit rates

\footnotetext{
republic than to understand on the basis of retrospective data how well informed the bank supervisory authorities were.

${ }^{14}$ One should note that there are important differences in local accounting standards for a transition economy like the Czech republic. Most transition economies still use accounting procedures carried over from central planning that reflect production rather then profit. It is striking how much local and international accounting standards differ. For instance, in 1992 Komercni banka reported a profit of 3.2 billion CZK and a loss of 5.9 billion CZK according to local and international standards, respectively. ${ }^{15}$ For instance, Cordella and Yeyati (1998) shows that when banks do not control their risk exposure, the presence of informed depositors may increase the probability of bank failures.

${ }^{16}$ Note that selection of other variables or probit specification gave similar results in terms of position of the regulators.
} 
alone (Model II) ${ }^{\square}$ This finding suggests that (unaudited) monthly balance sheets with detailed information used by the supervisory body of the CNB did not contain more information (but also not less) with respect to the prediction of actual bank failure than publicly available interest rate data. Thus, the CNB did not have more information than the market. Given the rather poor predictive power of models I and II, this suggests that, despite banking regulations, asymmetric information between the CNB and the banks remains a serious issue. More importantly, there is an interesting interaction between the information contained in financial ratios and retail interest rates. Looking at the results for the first half of 1995 we see that, although both Models I and II provide very similar (and not very good) predictions, combining them (Model III) significantly increases the quality of the predictions. ${ }^{18}$ This strategy suggests that the information of the CNB and of the market is not the same and that interest rate information complements the information contained in balance sheets. Note, however, an interesting difference between the results for the first and the second half of 1995. For the first half of 1995, model III is better than both models I and II. However, for the second half of 1995, there ceases to be a significant difference in the quality of prediction between models I and III. This suggests that the information in retail deposit rates is reflected in the bank balance sheet data for that period. A natural interpretation is that the signals provided by the interest rates were by then incorporated in the balance sheets. One possible scenario is that these early signals attract the attention of regulators who force the banks to provide more

\footnotetext{
${ }^{17}$ Previous t-tests suggest to using two-year deposit rates, although the reason for using one-year rates instead is simple. For two-year deposit rates we have a few missing observations: not every bank provided a table of retail interest rates by all maturities and several banks specified longer maturities as "negotiable". Since we do not want to lose more observations, we opted for one-year interest rate that was provided by all banks in our sample.
} 
accurate data, but one can think of various other scenarios. In any case, if there is a lag between the time when interest rates increase and the time this information is incorporated into the balance sheet data, then one should conclude that interest rate differentials can be seen as an early signal of banking distress.

\section{CONCLUSIONS}

Despite the small sample available, we provide evidence from the Czech banking crisis that the interest rates differentials between sound and problematic banks were significant and increasing as bank failures approached. Second, our data support the assumption that the bank supervisory body did not, despite, banking regulations and reporting requirements based on private balance sheets, have information (in terms of quality of early warning signals) superior to publicly available information incorporated in interest rates. These findings add to the general body of theoretical and empirical literature on the effects of informational asymmetries in the banking sector and on the adverse selection effects of interest rate competition. They highlight the difficulty of overcoming informational asymmetry between banks and the regulator. Despite calls for more transparency and better reporting rules, informational asymmetries are likely to continue to be an important part of the financial reality in emerging markets where fragile equity positions of banks will lead to increased risktaking with systemic consequences.

Two lessons stand out from a normative point of view. A first is that the market interest rates variable should be used to adjust for the default risk of the bank since it

\footnotetext{
${ }^{18}$ Note that neither Model I or II significantly dominate a naïve estimator $(=1)$, but their combination,
} 
is a useful early signal, especially in case of a fragile equity position. Moreover, our results suggest that it is useful to combine balance sheet and interest rate data since the information they provide is complementary, at least in early stages. In the Czech case this approach would significantly improve the quality of the bank supervision and upgrade any early warning signal. A second lesson relates to the importance of sound bank capitalization. Indeed, both our model and the empirical evidence suggest that bank passivity and perverse competition on interest rates are much less of an issue when banks are sufficiently capitalized.

Model III does. 
Table 1. Number of Banks in Operation in the Czech Republic, 1990 - 1997

\begin{tabular}{|l|l|l|l|l|l|l|l|l|}
\hline Number of banks, eop. & 1990 & 1991 & 1992 & 1993 & 1994 & 1995 & 1996 & 1997 \\
\hline \hline Total, of which & 9 & 24 & 37 & 52 & 55 & 54 & 53 & 50 \\
\hline Large banks & 5 & 6 & 6 & 6 & 6 & 6 & 5 & 5 \\
\hline Small banks & 4 & 14 & 19 & 22 & 21 & 18 & 12 & 9 \\
\hline Foreign banks & & 4 & 8 & 11 & 12 & 12 & 13 & 14 \\
\hline Foreign bank branches & & & 3 & 7 & 8 & 10 & 9 & 9 \\
\hline Specialised banks & & & 1 & 5 & 7 & 8 & 9 & 9 \\
\hline Banks under conservatorship & & & & 1 & 1 & & 5 & 4 \\
\hline \hline Banks without licence & & & & & 1 & 4 & 6 & \\
\hline
\end{tabular}

Source: Reports on Monetary Development in the Czech Republic, CNB 1994-1997

Report on Bank Supervision in the Czech Republic, CNB 1996

Table 2. Share of Total Assets, banks with valid licence as of 31 Dec.1997

\begin{tabular}{|l|l|r|r|r|r|}
\hline End of the period & 1993 & 1994 & \multicolumn{1}{c|}{1995} & \multicolumn{1}{c|}{1996} & \multicolumn{1}{c|}{1997} \\
\hline \hline Total banking sector, of which & 100 & 100.00 & 100.00 & 100.00 & 100.00 \\
\hline Large banks & & 77.18 & 71.72 & 68.87 & 65.67 \\
\hline Small banks & & 4.44 & 4.92 & 5.21 & 4.72 \\
\hline Foreign banks, incl. Branches & & 11.67 & 16.46 & 18.84 & 22.28 \\
\hline Specialised banks & & 1.47 & 2.11 & 3.09 & 4.29 \\
\hline Banks under conservatorship & & 5.24 & 4.78 & 4.00 & 3.04 \\
\hline \hline Banks without licence & & 0.64 & 2.24 & 2.42 & $* 2.10$ \\
\hline
\end{tabular}

Source: Reports on Monetary Development in the Czech Republic, CNB 1994-1997 Report on Bank Supervision in the Czech Republic, CNB 1996

Table 3. Consolidation Program of the CNB

\begin{tabular}{|l|c|c|}
\hline Consolidation was done by: & $\begin{array}{l}\text { Number } \\
\text { of Banks }\end{array}$ & $\begin{array}{l}\text { Share on the } \\
\text { Total Assets of } \\
\text { the banking } \\
\text { sector, June } \\
30,1996\end{array}$ \\
\hline \hline - reduction of shareholder's capital and conservatorship & 5 & 1.64 \\
\hline - closing the bank & 2 & 1.24 \\
\hline - selling the bank and subsequent merging & 3 & 1.66 \\
\hline - increasing the capital & 6 & 3.98 \\
\hline No consolidation needed & 3 & 1.13 \\
\hline \hline Total ${ }^{1)}$ & 18 & 8.84 \\
\hline
\end{tabular}

Source: Report on Bank Supervision in the Czech Republic, CNB 1996

1) For one bank two methods were combined: first, reduction of shareholder's capital and conservatorships; and then the bank was merged with other existing bank. 
Table 4. Minimum Reserve Requirement Rates since 1992

\begin{tabular}{|l|l|l|l|l|l|l|l|l|}
\hline & \multicolumn{6}{|l|}{ Rates (percent) effective by: } \\
\cline { 2 - 9 } & $11 / 92$ & $2 / 93^{*}$ & $7 / 93$ & $8 / 94$ & $8 / 95$ & $8 / 96$ & $5 / 97$ & $8 / 98$ \\
\hline \hline Demand deposits & 9 & $9-12$ & 9 & 12 & 8.5 & 11.5 & 9.5 & 7.5 \\
\hline Time deposits & 3 & $3-4$ & 3 & 12 & 8.5 & 11.5 & 9.5 & 7.5 \\
\hline
\end{tabular}

* Lower rate was used for banks with deposits up to 25 billion CZK, otherwise the higher rate was applied.

Source: CNB, Monetary indicators.

Table 5. Comparison of average deposit rates (control group vs. problematic banks). Semiannual data from June 1993 to December 1995

\begin{tabular}{|c|c|c|c|c|}
\hline Year & Group & $\begin{array}{c}\text { checking } \\
\text { account }\end{array}$ & $\begin{array}{c}\text { 1year term } \\
\text { deposit }\end{array}$ & $\begin{array}{c}2 \text { years term } \\
\text { deposit }\end{array}$ \\
\hline \multirow{3}{*}{1993.1} & "control" & 3.48 & 12.95 & 14.53 \\
\hline & "problematic" & 4.44 & 13.74 & 14.36 \\
\hline & $\mathrm{p}$-value (t-tests) & $.05 * *$ & 0.16 & 0.4 \\
\hline \multirow{3}{*}{1993.2} & "control" & 3.97 & 13.05 & 14.44 \\
\hline & "problematic" & 4.29 & 13.95 & 14.72 \\
\hline & $\mathrm{p}$-value (t-tests) & 0.27 & $.03 * *$ & 0.22 \\
\hline \multirow{3}{*}{1994.1} & "control" & 3.61 & 10.51 & 13.42 \\
\hline & "problematic" & 4.21 & 11.75 & 13.6 \\
\hline & $\mathrm{p}$-value (t-tests) & 0.18 & $.05 * *$ & $.00 * * *$ \\
\hline \multirow{3}{*}{1994.2} & "control" & 3.4 & 9.82 & 12.83 \\
\hline & "problematic" & 4.36 & 10.80 & 14.51 \\
\hline & $\mathrm{p}$-value (t-tests) & $.08 *$ & $.10^{*}$ & $.05 * *$ \\
\hline \multirow{3}{*}{1995.1} & "control" & 3.17 & 9.45 & 11.68 \\
\hline & "problematic" & 4.47 & 10.61 & 13.67 \\
\hline & p-value (t-tests) & $.01 * * *$ & $.03 * *$ & $.00 * * *$ \\
\hline \multirow{3}{*}{1995.2} & "control" & 3.56 & 9.62 & 11.15 \\
\hline & "problematic" & 4.68 & 10.63 & 12.92 \\
\hline & $\mathrm{p}$-value (t-tests) & $.03 * *$ & $.01 * * *$ & $.01 * * *$ \\
\hline
\end{tabular}

Significant at $1 \%$ level, ** Significant at 5\% level _ $\quad$ * Significant at $10 \%$ level. 
Table 6. Comparison of logit models. Standard errors are in parenthesis.

\begin{tabular}{|l|c|c|c|c|c|c|}
\hline \multirow{2}{*}{ Variable } & \multicolumn{3}{|c|}{ Period 1995/1 } & \multicolumn{3}{c|}{ Period 1995/2 } \\
\cline { 2 - 7 } & I. & II. & III. & I. & II. & III. \\
\hline \hline Capital adequacy & .10 & & -.53 & .17 & & -.54 \\
& $(.65)$ & & $(.39)$ & $(.11)$ & & $(.49)$ \\
\hline Equity multiplier & -.05 & & 2.57 & -.04 & & -1.4 \\
& $(.09)$ & & $(1.6)$ & $(.11)$ & & $(1.2)$ \\
\hline Return on Assets & -.31 & & -.82 & -.23 & & -.01 \\
& $(.22)$ & & $(.61)$ & $(.56)$ & & $(.88)$ \\
\hline Classified Loans Coverage by & .05 & & -.83 & -1.9 & & -3.0 \\
Provisions & $(.07)$ & & $(.70)$ & $(1.3)$ & & $(2.9)$ \\
\hline $\begin{array}{l}\text { One year term deposit rate (the } \\
\text { lowest) }\end{array}$ & & .15 & 2.68 & & .07 & 1.3 \\
$(.11)$ & $(1.8)$ & & $(.14)$ & $(1.5)$ \\
\hline One year term deposit rate (the & & -.14 & -.85 & & -.02 & .49 \\
highest) & & $(.18)$ & $(.84)$ & & $(.22)$ & $(1.1)$ \\
\hline R-square & 0.1 & 0.09 & 0.71 & 0.35 & 0.06 & 0.69 \\
\hline Fraction of Correct Prediction & 0.65 & 0.7 & 0.9 & 0.75 & 0.63 & 0.88 \\
\hline \hline Test I. vs. II. (p-value) & \multicolumn{2}{|c|}{$\Pi^{2}(1)=0.20(.65)$} & $\Pi^{2}(1)=0.67(.41)$ \\
\hline Test II. vs. III. (p-value) & \multicolumn{2}{|c|}{$\Pi^{2}(1)=2.67(.10)^{*}$} & $\Pi^{2}(1)=2.67(.10)^{*}$ \\
\hline Test I. vs. III. (p-value) & \multicolumn{2}{|c|}{$\Pi^{2}(1)=3.57(.06)^{*}$} & \multicolumn{2}{|c|}{$\Pi^{2}(1)=1.0(.32)$} \\
\hline
\end{tabular}

** Significant at 5\% level, * Significant at $10 \%$ level.

${ }^{+}$The test reported here is a chi-square test of whether one model dominates the other in terms of predictive accuracy. The null hypothesis is that there is no difference between these models in predictive accuracy. Denote by "+" the cases where models correctly predicted the dependent variable, and denote by "-" where they do not. The quality of the prediction can then be summarized in the following table:

\begin{tabular}{|c|c|cc|c|}
\hline \multicolumn{2}{|c|}{} & \multicolumn{2}{|c|}{ Model 1 } & \multirow{2}{*}{$\Gamma$} \\
\cline { 2 - 3 } & + & - & \\
\hline$\frac{\mathrm{D}}{\frac{\delta}{\delta}}$ & + & $\mathrm{n}_{11}$ & $\mathrm{n}_{12}$ & $\mathrm{n}_{1 .}$ \\
\hline$\Gamma$ & - & $\mathrm{n}_{21}$ & $\mathrm{n}_{22}$ & $\mathrm{n}_{2 .}$ \\
\hline$\Gamma$ & $\mathrm{n}_{.1}$ & $\mathrm{n}_{.2}$ & $\mathrm{n}$ \\
\hline
\end{tabular}

Corresponding test statistics

$\chi_{1}^{2}=\frac{\left(n_{12}-n_{21}\right)^{2}}{n_{12}+n_{21}}$ has a chi-square distribution with 1 degree of freedom. For more details, see Hanousek, 2000 

Figure 1 .One Year Retail Deposit Rates (the highest)
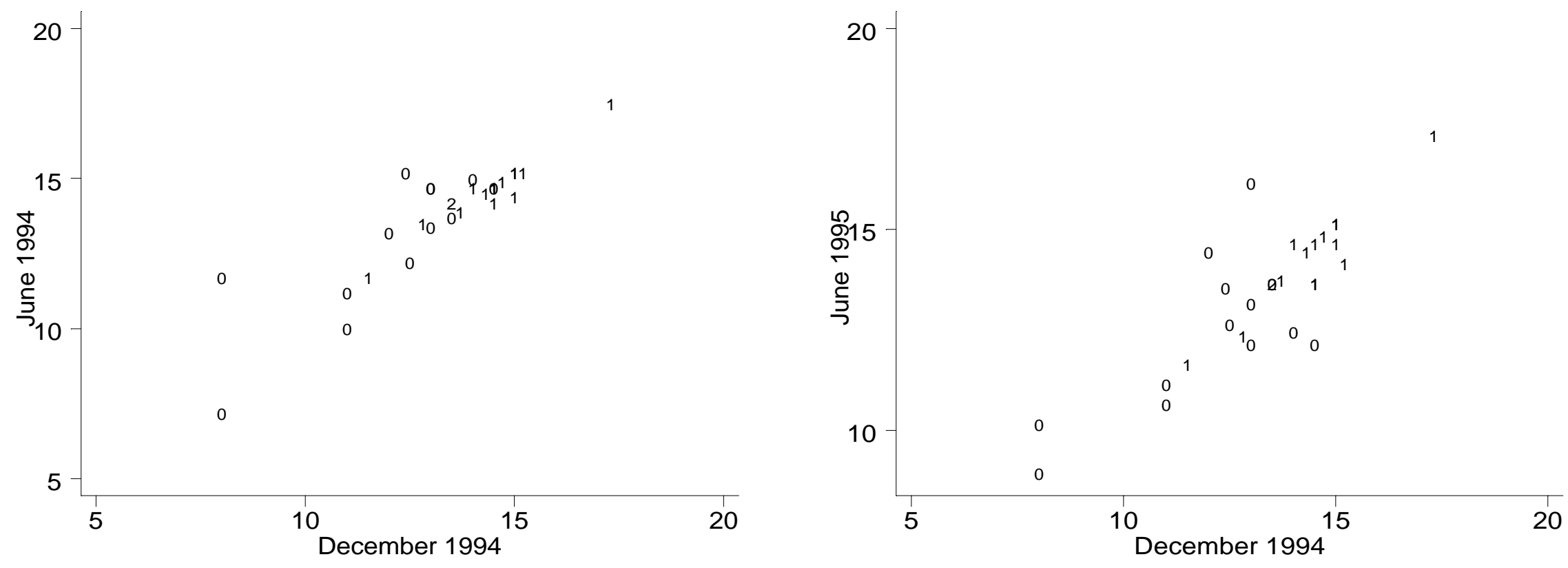

Symbol " 1 " indicates the banks that failed during the period 1994-1996, while "0" denotes those banks which "survived". As a benchmark (denoted by 2) we used "Plzenska banka", the bank that provided practically no corporate lending, and therefore, their interest rates should not reflect problems with their portfolio of loans. 



\section{References}

Anderson, R., Berglof, E., 1996. Organisation of Banks in the CEE Economies. In: Anderson, R., Berglof, E., Mizei, (Eds.), Banking Sector Development in Central and Eastern Europe.

Aghion, P., Bolton, P., Fries, S., 1998. Optimal Design of Bank Bailouts: The Case of Transition Economics, EBRD Working Paper 32, 1998.

Barber, J.R., Chang, C.H., Thurston, D.F., 1996. Bank Failure, Risk, and Capital Regulation, Journal of Economics and Finance 20(3), 13-20.

Berglöf, E., Roland, G., 1997. Soft budget constraints and credit crunches in financial transition, European Economic Review 41, 807-818.

Bolton, P., Freixas, X., 2000. Equity, Bonds, and Bank Debt: Capital Structure and Financial Market Equilibrium under Asymmetric Information, Journal of Political Economy 108(2), 324351.

Caprio, G., 1995. The Role of Financial Intermediaries in Transitional Economies, CarnegieRochester Conference Series on Public Policy 42, 257-302.

Cole, R.A., McKenzie, J.A., White, L.J., 1995. Deregulation goes Awry: Moral Hazard in the Savings and Loan Industry. In: Cottrell, A., Lawlon, M., Woo, J. (Eds.), The Causes and Consequences of Depository Institution Failures. Kluwer, Boston, MA, 29-73.

Corbett, J., Mitchell, J., 2000. Banking Crisis and Bank Rescues: The Effect of Reputation, CERGE-EI Research Seminar Series, Prague, February 2000.

Cordella,T., Yeyati, E.L., 1998. Public Disclosure and Bank Failures, IMF Staff Papers 45(1), March 1998, 110-131.

Czech National Bank, Annual Report, 1993-1999.

Czech National Bank. Monetary Indicators, 1993-1999.

Czech National Bank, 1996. Banking Supervision in the Czech Republic.

Demirgüc-Kunt, A., Detragiache, E., 1997. The Determinants of Banking Crises: Evidence from Developed and Developing Countries, World Bank.

Demirgüc-Kunt, A., Detragiache, E., 1998. Financial Liberalization and Financial Fragility. In: Pleskovic, B., Stiglitz, J.E., (Eds.), Annual World Bank Conference on Development Economics, Washington D.C., 303-331.

Dewatripont, M., Maskin, E., 1995. Credit and Efficiency in Centralized and Decentralized Economies, Review of Economic Studies 62, 541-555.

Diamond, D.W., 1984. Financial Intermediation and Delegated Monitoring, Review of Economic Studies 51, 393-414. 
EBRD, 1996-1999. Transition Report, European Bank for Reconstruction and Development, London.

Ellis, D.M., Flannery, M.J., 1992. Does the Debt Market Assess Large Banks' Risk? Time Series Evidence from Money Center CDs, Journal of Monetary Economics 30, 481-502.

Hannan, T. H., Hanweck, G.A., 1988. Bank Insolvency Risk and the Market for Large Certificates of Deposit, Journal of Money, Credit and Banking 2, 203-212.

Hanousek, J., 2000. Note on Specification Tests of (Binary) Choice Models: A Non-Parametric Approach, Central European Journal of Operation Research 8:3, 259-264.

Hellman, T.F., Murdock, K. C., Stiglitz, J.E., 2000. Liberalization, Moral Hazard in Banking, and Prudential Regulation: Are Capital Requirements Enough?, American Economic Review 90(1), 147-165.

Hwang, D.Y, Lee, C.F., Liaw, K.T., 1997. Forecasting Bank Failures and Deposit Insurance Premium, International Review of Economics and Finance 6(3), 317-34.

Kane, E., 1989. The S and L Insurance Crisis: How Did it Happen?, Urban Institute Press, Washington D.C..

Lane, W.R., Looney, S.W., Wansley, J.W., 1986. An Application of the Cox Proportional Hazard Model to Bank Failure, Journal of Banking and Finance, 511-531.

Lindren C.-J., et al. 1996. Bank Soundness and Macroeconomic Policy, IMF, Washington.

Looney, S.W., Wansley, J.W., Lane, W.R., 1989. An Examination of Misclassification with Bank Failure Prediction Models, Journal of Economics and Business 41, 327-336.

Marcus, A.J., 1984. Deregulation and Bank Financial Policy, Journal of Banking and Finance 8, 557-565.

Martin, D., 1977. Early Warning of Bank Failure: A Logit Regression Approach, Journal of Banking and Finance, 249-276.

Meyer, P.A., Pifer, H.W., 1970. Prediction of Bank Failure, Journal of Finance, 853-868.

Mitchell, J., 1993. Creditor Passivity and Bankruptcy: Implications for Economic Reform. In: Mayer, C., Vives, X., (Eds.), Capital Markets and Financial Intermediation, Cambridge University Press, 197-224.

Mitchell, J., 1997. Strategic Creditor Passivity, Regulation, and Bank Bailouts, CEPR Discussion Paper 1780, London.

Mitchell, J. 1998. The Problem of Bad Debts: Cleaning Banks' Balance Sheets in Economics in Transition, CEPR Discussion Paper 1977, London. 
Rajan, R. 1994. Why Bank Credit Policies Fluctuate: A Theory and Some Evidence, Quarterly Journal of Economics 109:2, 399-442.

Rochet, J.-Ch., 1992. Capital Requirements and the Behaviour of Commercial Banks, European Economic Review 36(5), 1137-1170.

Vojtisek, P., 1993. Restructuring of the Banks in the Former Czech and Slovak Federal Republic. In: OECD Transformation of the Banking System.

West, R.C., 1985. A Factor-Analytic Approach to Bank Condition, Journal of Banking and Finance, 253-266.

Wheelock, D. C., Wilson, P.W., 1995. Explaining Bank Failures: Deposit Insurance, Regulation, and Efficiency, The Review of Economics and Statistics, 689-700. 


\section{DAVIDSON INSTITUTE WORKING PAPER SERIES - Most Recent Papers}

The entire Working Paper Series may be downloaded free of charge at: www.wdi.bus.umich.edu

CURRENT AS OF $1 / 18 / 02$

\begin{tabular}{|c|c|c|}
\hline Publication & Authors & Date \\
\hline $\begin{array}{l}\text { No. 424: Banking Passivity and Regulatory Failure in Emerging } \\
\text { Markets: Theory and Evidence from the Czech republic. }\end{array}$ & Jan Hanousek and Gerard Roland & July 2001 \\
\hline $\begin{array}{l}\text { No. 423: Conceptions of the Corporation and the Prospects of } \\
\text { Sustainable Peace }\end{array}$ & Jeffrey Nesteruk & Dec. 2001 \\
\hline No. 422: The Role of the Corporation in Fostering Sustainable Peace & Timothy Fort and Cindy Schipani & Nov. 2001 \\
\hline No. 421: Wage Arrears and the Distribution of Earnings in Russia & $\begin{array}{l}\text { Hartmut Lehmann and Jonathan } \\
\text { Wadsworth }\end{array}$ & Dec. 2001 \\
\hline $\begin{array}{l}\text { No. 420: Transferring Collective Knowledge: Collective and } \\
\text { Fragmented Teaching and Learning in the Chinese Auto Industry }\end{array}$ & $\begin{array}{l}\text { Jane Zhou, Jaideep Anand, and } \\
\text { Will Mitchell }\end{array}$ & Dec. 2001 \\
\hline $\begin{array}{l}\text { No. 419: Liberalization, Corporate Governance, and the Performance of } \\
\text { Newly Privatized Firms }\end{array}$ & $\begin{array}{l}\text { Narjess Boubakri, Jean-Claude } \\
\text { Cosset, and Omrane Guedhami }\end{array}$ & Dec. 2001 \\
\hline $\begin{array}{l}\text { No. 418: The European Data Privacy Directive and International } \\
\text { Relations }\end{array}$ & Steven R. Salbu & Dec. 2001 \\
\hline $\begin{array}{l}\text { No. 417: Capital Markets and Capital Allocation: Implications for } \\
\text { Economies in Transition }\end{array}$ & $\begin{array}{l}\text { Artyom Durnev, Randall Morck, } \\
\text { and Bernard Yeung }\end{array}$ & Dec. 2001 \\
\hline $\begin{array}{l}\text { No. 416: Forthcoming in: The Journal of Economic Perspectives, "Data } \\
\text { Watch. Research Data from Transition Economies," 16(2) Feb. } 2002 .\end{array}$ & $\begin{array}{l}\text { Randall K. Filer and Jan } \\
\text { Hanousek }\end{array}$ & Dec. 2001 \\
\hline $\begin{array}{l}\text { No. 415: Forthcoming in: The Journal of Economic Perspectives, } \\
\text { "Transition Economies: Performance and Challenges," 16(2) Feb. } 2002 .\end{array}$ & Jan Svejnar & Dec. 2001 \\
\hline $\begin{array}{l}\text { No. 414: Forthcoming in: The Journal of Economic Perspectives, "The } \\
\text { Great Divide and Beyond: Financial Architecture in Transition," 16(2) } \\
\text { Feb. 2002. }\end{array}$ & Erik Berglof and Pat & Dec. 2001 \\
\hline $\begin{array}{l}\text { No. 413: Forthcoming in: The Journal of Economic Perspectives, "The } \\
\text { Political Economy of Transition," 16(2) Feb. } 2002 .\end{array}$ & Gérard Roland & Dec. 2001 \\
\hline $\begin{array}{l}\text { No. 412: The Response of Consumption in Russian Households to } \\
\text { Economic Shocks }\end{array}$ & Steven Stillman & Oct. 2001 \\
\hline No. 411: Mark-ups in Hungarian Corporate Sector & László Halpern and Gábor Kőrösi & Aug. 2001 \\
\hline No. 410: Economic Development, Legality, and the Transplant Effect & $\begin{array}{l}\text { Daniel Berkowitz, Katarina } \\
\text { Pistor, Jean-Francois Richard }\end{array}$ & Sept. 2001 \\
\hline No. 409: Development Strategy, Viability, and Economic Convergence & Justin Yifu Lin & Oct. 2001 \\
\hline No. 408: Labor Supply, Informal Economy and Russian Transition & Maxim Bouev & May 2001 \\
\hline No. 407: Corporate Governance in China: Then and Now & Cindy Schipani and Liu Junhai & Nov. 2001 \\
\hline No. 406: Entrepreneurship and Post-Socialist Growth & $\begin{array}{l}\text { Daniel Berkowitz and David N. } \\
\text { DeJong }\end{array}$ & Oct. 2001 \\
\hline $\begin{array}{l}\text { No. 405: Forthcoming in: European Economic Review, "Policy Reform } \\
\text { and Growth in Post-Soviet Russia." }\end{array}$ & $\begin{array}{l}\text { Daniel Berkowitz and David N. } \\
\text { DeJong }\end{array}$ & Oct. 2001 \\
\hline $\begin{array}{l}\text { No. 404: Social Policies and Structures: Institutional Frictions and Traps } \\
\text { in the Czech Republic after } 1989\end{array}$ & Jiří Večerník & Nov. 2001 \\
\hline $\begin{array}{l}\text { No. 403: Investment, Efficiency, and Credit Rationing: Evidence from } \\
\text { Hungarian Panel Data }\end{array}$ & Mathilde Maurel & Nov. 2001 \\
\hline $\begin{array}{l}\text { No. 402: Subduing High Inflation in Romania. How to Better Monetary } \\
\text { and Exchange Rate Mechanisms? }\end{array}$ & $\begin{array}{l}\text { Daniel Daianu and Radu } \\
\text { Vranceanu }\end{array}$ & Aug. 2001 \\
\hline $\begin{array}{l}\text { No. 401: The Gender Wage Gap in Bulgaria: A Semiparametric } \\
\text { Estimation of Discrimination }\end{array}$ & Dean Jolliffe & July 2001 \\
\hline $\begin{array}{l}\text { No. 400: Do External Auditors Perform a Corporate Governance Role in } \\
\text { Emerging Markets? Evidence from East Asia }\end{array}$ & Joseph P. H. Fan and T.J. Wong & Oct. 2001 \\
\hline $\begin{array}{l}\text { No. 399: Financial Conditions and Investment during the Transition: } \\
\text { Evidence from Czech Firms }\end{array}$ & Lubomír Lízal and Jan Svejnar & 001 \\
\hline
\end{tabular}

